\title{
Creation, Light, and Redemption
}

\author{
Hexaemeral Thinking, Robert Grosseteste, \\ and the Summa Halensis
}

\begin{abstract}
This paper will explore the evolution of Robert Grosseteste's thought on creation, in particular as presented in the Hexaemeron, the commentary on the six days of creation, and the theme of light in particular. The background to Grosseteste's thought amongst patristic and twelfth-century authors will be explored in some detail, as well as contemporary mystical theology, clerical and lay. Interest in light will be overlain with questions of how scientific thought is presented in exegetical theology, as well as more speculative theological issues connected to redemption, the essential counterpoint to creation, and its fulfilment. In particular comparison will be made to Franciscan thought on the matter, notably that of the Summa Halensis, composed between 1236-45 under the direction of Alexander of Hales and John of La Rochelle.
\end{abstract}

On his return from Lyons, probably in September or October of 1245, Robert Grosseteste then Bishop of Lincoln (1235-53), wrote to William of Nottingham, minister of the English province of Franciscans, to explain some complications of his journey. Grosseteste, in company with Adam Marsh and John of Stamford had planned to travel down the Seine to Paris, and then on to Rouen, where John would have stayed with the Franciscan community there, and Adam would have moved on to the coast where he would meet Grosseteste. John's illness was so severe, however, that he and Adam only reached the town of Montes-la-Jolie, about 32 miles downriver from Paris. Grosseteste urged William of Nottingham to send out Peter of Tewkesbury and one or more friars to stay with John until his recovery. Anticipating his own arrival on the Isle of Wight as around 14 October, Grosseteste also asked that Peter should rendezvous with him there before travelling across the channel. John evidently did recover and became eventually provincial minister in succession to Peter of Tewkesbury in 1258.

Grosseteste had two further items on which to report. The first was that the Pope had come down in favour of the visitation of the Lincoln Dean and Chapter by their bishop, which they had resisted ever since Grosseteste's election. Second, the following piece of news:

Furthermore, you should know that it is not safe for Brother Adam to extend his stay in these parts, as there are many who very much want to keep him in Paris, especially now that Alexand- 
er of Hales and John of La Rochelle are dead. If that were to happen, both you and I would be robbed of our greatest comfort-which God forbid! ${ }^{1}$

Alexander had died in August 1245, John a little earlier in February of the same year; both had been co-regents in the Franciscan schools at Paris. Alexander joined the Franciscan order in 1236, arranged the appointment of John of La Rochelle in 1238, partly through the good offices of William of Auvergne (1180x90 -1249), Bishop of Paris from 1228.

An earlier letter from Grosseteste to William of Auvergne implies a close relationship between the two men, the former addressing the latter as amicus carissimus. ${ }^{2}$ The letter then introduces its bearer and, using the image of moisture filling the smallest of cavities to indicate the capacity of William's affection to infuse everyone, asks that he should extend the same affection shown to Grosseteste to the bearer of the letter, who is a small part of his master's equally small self. It was perhaps William who was the source of Grosseteste's information in addition to the Franciscan circles with which he and his travelling companions were familiar. The letter to William of Nottingham is the only one in Grosseteste's collection to mention Alexander or John of La Rochelle, nor are they the recipients themselves of any other known missive or message.

Nevertheless it is worth noting that Alexander of Hales, born in about 1185 was a near-contemporary of Grosseteste, born around $1170 .{ }^{3}$ Alexander and his family are associated with Hales, Shropshire, now Halesowen, and only some 45 miles from Hereford in which diocese the younger Grosseteste found employment at the episcopal court of William de Vere from c.1195-99, and later appears to have worked, according to an intermittent documentary record for Archdeacon Hugh Foliot, himself Bishop of Hereford 1219-34. Where Alexander can be placed more confidently amongst the ranks of scholars trained at the University of Paris, master of arts probably in 1210 incepting in theology two years or so later, and regent master in or around 1220, Grosseteste's institutional affiliations are more difficult to trace. He appears to have been in France during the English interdict of 1208-1213, though in

1 Robert Grosseteste, Roberti Grosseteste Episcopi quondam Lincolniensis Epistolae, Letter 114, ed. Henry Richards Luard (London: Longman, Green, Longman, and Roberts, 1861), 335: 'cum plures multum desiderent ipsum Parisius detinere, maxime mortuis fratribus Alexandro de Hales et J. de Rupellis; et sic tam vos quam nos maximo nostro solatio essemus destituti, quod absit.' English translation from Robert Grosseteste, The Letters of Robert Grosseteste, Bishop of Lincoln, trans. F.A.C. Mantello and Joseph W. Goering (Toronto: University of Toronto Press, 2010), 352.

2 Grosseteste, Epistolae 78 (Luard, 250; Mantello and Goering, 270-1).

3 On Alexander see C.H. Lawrence, 'Hales, Alexander of (c. 1185-1245), Franciscan friar and theologian,' Oxford Dictionary of National Biography, September 23, 2004. Retrieved December 18, 2018. https://www.oxforddnb.com/view/10.1093/ref:odnb/9780198614128.001.0001/odnb-9780198614128-e327?rskey=p1hmwX\&result=1. The main biography of Grosseteste remains Richard W. Southern, Robert Grosseteste: The Growth of an English Mind in Medieval Europe, 2nd ed. (Oxford: Oxford University Press, 1992). See also James McEvoy, Robert Grosseteste (Oxford: Oxford University Press, 2000). 
what capacity is not known, and he may have visited Paris after in the late 12teens or early 1220s, with a longer visit possible in about 1225 . Grosseteste's connections to Oxford are demonstrable, but only in the late 1220s, and his appointment as lector to the Franciscan community newly established in the city, the nostrum of his 'Chancellorship' of the university in 1215, whatever that entailed, being put to one side. ${ }^{4}$ When and where Grosseteste's regency in theology took place is difficult to establish, although, as Ginther suggests, the evidence points to the years $1229-1235 .^{5}$ It is plausible that Grosseteste was teaching in the secular schools at Oxford a little before this date. $^{6}$

Both Grosseteste and Alexander were, however, Archdeacons at the same time, and in contiguous districts. Grosseteste was made Archdeacon of Leicester in Lincoln diocese in 1229 until he resigned in $1232 .{ }^{7}$ Alexander was made Archdeacon of Coventry in the diocese of Lichfield and Coventry in 1231 which he held until early 1236 and his entry into the Franciscan order. He appears to have been active in England in 1231, adjudicating in a dispute between the abbeys of Combe and Leicester in 1232. Given these circumstances, it is possible that the two men were acquainted and highly likely that they were known to each other by reputation.

The connections grow stronger with Grosseteste's association with the Franciscans of Oxford. His appointment as lector to the community, coupled with his later eagerness for additions to his household as Bishop of Lincoln from the mendicant orders, and his long friendship with Adam Marsh, who took up the Franciscan habit in 1233/4, ensured a positive place for Grosseteste within English Franciscan historical memory. Thomas of Eccleston's account of the establishment of the order in England underlines the emphasis given to Grosseteste at Oxford, in a section on the appointment of lectors:

In that celebrated place, where the first learning flourished in England, and where the community of scholars was used to meeting, Brother Agnellus established a sufficiently worthy school at the Brothers' location [Greyfriars], and requested and secured agreement from Robert Grosseteste of sacred memory that he would lecture there for the brothers. Under him they made inestimable progress within a short period of time, both in questions and in subtle morality suitable for preaching. When he therefore was translated by divine providence from the magisterial [office] to an episcopal seat, Master Peter, who was later appointed as Bishop in Scotland, lectured to the Brothers at the same place. ${ }^{8}$

4 Southern, Robert Grosseteste, xxIx-xxxiI.

5 James R. Ginther, Master of the Sacred Page: A Study of the Theology of Robert Grosseteste, ca. 1229/ 30-1235 (Aldershot: Ashgate, 2004), 5.

6 Southern, Robert Grosseteste, $70-5$.

7 Southern, Robert Grosseteste, 75. See also Grosseteste, Epistolae 8 and 9 (Luard, 43-7; Mantello and Goering, 75-80).

8 Thomas of Eccleston, Tractatus De Adventu Fratrum Minorum in Angliam, ed. A.G. Little (Manchester: Manchester University Press, 1951), 48: 'Ampliato loco, ubi principale studium florebat in Anglia, et ubi universitas scholarium convernire consuevit, fecit frater Agnellus scholam satis honestam aedificari in loco fratrum, et impetravit a sanctae memoriae magistro Roberto Grosseteste, ut legeret ibi 
Agnellus, to whom Grosseteste wrote between 1229 and 1232 commiserating with him, and the Oxford Franciscans, on the departure of Adam Rufus to preach to the Saracens, was the provincial minister of the order for England. ${ }^{9}$ Elsewhere in Eccleston's account Grosseteste's learning, wisdom, and gifts for pastoral care are stressed. The Lancercost Chronicle, with its Franciscan core, is similarly laudatory of Grosseteste's formative role on the English Franciscans and his keen prosecution of the ideals of church reform, personal and institutional. ${ }^{10}$

By 1245 Grosseteste had been Bishop of Lincoln for a decade, and the recently deceased Alexander a Franciscan for a similar length of time. Alexander had retained his position in the faculty of theology within the University of Paris on moving to the Franciscans, creating an important precedent for the order in this respect. Grosseteste's letter to William of Nottingham is indicative of the personal and institutional networks that existed between Grosseteste, the English Franciscans and the circles of Alexander and John of La Rochelle. Connections can be made also in terms of theological interest. One overlap of considerable importance is thought about creation. The doctrine of creation takes centre-stage for Grosseteste from the mid-to-late 1220s, whenever his magistracy began, and into the period as lector to the Franciscans up to the first years of his episcopacy. Over these years he lectured on Genesis and drew together the complex threads of the Hexaemeron. Written up, probably in 1235, the Hexaemeron marks, alongside the commentary on Aristotle's Posterior Analytics one of Grosseteste's more finished pieces. The theology of creation is to be found in other of Grosseteste's works. On the Cessation of the Laws, dating to a similar period as the Hexaemeron and following a similar evolution from lectures to written text, raises the question of whether Christ would have become incarnate even without the sin of Adam and Eve. The Anglo-Norman poem Le Château d'Amour was probably composed in the same period, and probably in the context of his Franciscan lectorship. Grosseteste compiled, then, a triptych of treatises dealing with various aspects of creation, for various audiences over the period from the late 1220 s to about 1235.

Chronologically these works emerge from Grosseteste's magistracy in theology and his duties at the Oxford Greyfriars, and also overlap with his mature writings on natural philosophy or science. Grosseteste's commentary on Aristotle's Posterior

fratribus. Sub quo inaestimabiliter infra breve tempus tam in quaestionibus quam praedicationi congruis subtilibus moralitatibus profecerunt. Ipso igitur ab cathedra magistrali in cathedram pontificalem providentia divina translato, legit fratribus ibidem magister Petrus qui postmodum in episcopum in Scotia promotus est.'

9 Grosseteste, Epistolae 2 (Luard, 17-21; Mantello and Goering, 49-53).

10 Joseph Stevenson, Chronicon de Lanercost, 1201-1346 (Edinburgh: the Bannatyne Club, 1839); A.G. Little, 'The Authorship of the Lanercost Chronicle,' English Historical Review 31 (1916): $269-79$. The original was known in the $16^{\text {th }}$ century as the chronicle of Friar Richard of Durham, although it was the work of at least two separate Franciscans in the period of compilation and composition. 
Analytics and the unfinished commentary on the Physics date from the mid 1220s, along with a number of scientific opuscula. These include the treatises De luce, De colore, De iride, De motu supercelestium, De motu corporali et de luce, De lineis, and De natura locorum. Major themes amongst this corpus include the definition of science, motion-first motion, circular and rectilinear-and the role of light and light-rays in the physical universe. At some time between 1229 and 1232 Grosseteste's Dicta appear to have taken shape, although he edited them later in his episcopacy. A collection of disconnected pieces, short and long, the Dicta include commentary on the first 50 psalms, sermons, and reflections on various moral or scientific subjects. They represent the broadening of Grosseteste's interests and responsibilities in their mixing of science, exegesis and speculative theology, and pastoral theology. The Cessation of the Laws, Château d'Amour, and Hexaemeron operate in the same way. All of these works, it should be noted, pre-date Grosseteste's first-hand knowledge of Greek.

By the early 1230s, then, Grosseteste was intimately connected to the growing Franciscan community, in England and in the wider network to which it belonged. He was acquainted, it would seem, with William of Auvergne, moved in circles in which a further acquaintance with Alexander of Hales was possible, and had developed a particular theological interest in creation and redemption, alongside a longstanding interest in the physical universe, given greater depth through a systematic engagement with Aristotle and Ibn Rushd (Averroes). All of these experiences predate the compilation of the Summa Halensis, making Grosseteste's thought prima facie a possible source for the compilers. In what follows the themes of redemption and light will be traced in Grosseteste, and a longer arc taken through creation theology. This involves in particular the genre of the Hexaemeron focusing especially the place of light and its treatment within the tradition. This longer contextualisation allows the achievement of Grosseteste, and the Franciscans to be appreciated, both in terms of faithfulness to the tradition, but also in their development of more radical directions of thought. In the case of Grosseteste this includes the extent to which scientific ideas are explored, and these in turn form part of the consideration of hexaemeral writing from the Patristic period onwards. Light provides a unifying theme across the tradition, its literal and allegorical interpretation provoke a wide range of theological questions and positions, and it is of cardinal importance in particular to Grosseteste's cosmological and Christological thought. A survey of light and the hexaemeral tradition, will be followed by Grosseteste's thoughts on the matter, his position on redemption in the Cessation of the Laws, and the Château d'Amour, and comparison to the Summa Halensis. 


\section{Hexaemeronic Thinking on Light}

Grosseteste composed his Hexaemeron towards the end of his regency in theology, a productive period of writing if the theological works are taken as the Commentary on Psalms, the extracts of Glosses on the Pauline Epistles and comments on Galatians, the Hexaemeron and the De cessatione legalium (preserving the lectures on Genesis, Daniel and Isaiah), the records of disputation, De dotibus, De veritate, De ordine and De libero arbitrio, a number of sermons from the Dicta, and the pastoral works De decem mandatis and the Speculum confessionis and the first ten letters of his collection. ${ }^{11}$ The Hexaemeron draws, probably, on a series of lectures on Genesis, and to a more limited extent, Isaiah. ${ }^{12}$ It is a treatise which involves Grosseteste in thinking about light on a number of different levels, in the context of the tradition, and his wider thinking about the relationship between creation and redemption. To examine Grosseteste's work is to see a yet more complex conglomeration of Patristic arguments and sources and original thought. Patristic sources are regularly cited, with due consideration to their arguments: Basil, Ambrose, Bede, Jerome, John of Damascus and Augustine, amongst others. As pertaining to light, the topics covered include familiar topics within the genre: the question of darkness over the deep, heresies which claim that power for darkness, the creation of light in the Word, the light of the world, the nature of the original light and how day and night were arranged without the sun, and detailed discussion of the luminaries. ${ }^{13}$ Grosseteste does not simply record proof texts, but quotes his authorities at length, and critically. ${ }^{14}$ He added sections as well, drawing on his own previous investigations of natural phenomena, for example, a lengthy section on the physical qualities of light which, as will be explored later, is closely related to the treatise De luce. No other hexaemeral author adds to the genre in quite the same way or to so great and extent. How Grosseteste interacted with the tradition of hexaemeral writing is perhaps best shown by exploring the material he encountered, and then tied, in this case, to thinking on light. In these circumstances it was Basil the Great, rather than Augustine, who took pride of place.

11 Ginther, Master of the Sacred Page, 13-24.

12 Giles E.M. Gasper, 'The Fulfillment of Science: Nature, Creation and Man in the Hexaemeron of Robert Grosseteste,' in Robert Grosseteste and the Pursuit of Religious and Scientific Learning in the Middle Ages, ed. Jack Cunningham and Mark Hocknull, Studies in the History of Philosophy of Mind, 18 (Heidelberg: Springer, 2016), 223.

13 Robert Grosseteste, Hexaemeron 1.18.1, 1.23.1-2, 2.1, 5.1-6, ed. Richard C. Dales and Servus Gieben, Auctores Britannici Medii Aevi, 6 (Oxford: Oxford University Press, 1982), 77, 82-3, 85-6, 158-63. For the history of earlier efforts to make a critical edition, see Gasper, 'The Fulfillment of Science,' 222.

14 See Neil Lewis, 'Robert Grosseteste and the Church Fathers,' in The Reception of the Church Fathers in the West: From the Carolingians to the Maurists, vol. 1, ed. Irena Backus (Leiden: Brill, 1997), 197-229, esp. 206. 


\section{Patristic Voices: Basil the Great and Ambrose of Milan}

The genre of commentary on the six days of creation was created, to all intents and purposes, by Basil, a copy of whose Hexaemeron in the Latin translation by Eustathius Grosseteste borrowed from the monks at Bury St Edmunds. ${ }^{15}$ Probably delivered as Lenten homilies in or around 370, the nine homilies cover the six days of creation, except for the creation of man. This was left to Gregory Nyssen to complete in a text translated along with Basil's homilies, and well-known in the medieval West as De conditione hominis (occasionally recorded in catalogues as De opificio hominis). The basis of Basil's preaching in the homilies is the ability to perceive and apprehend the Creator from the wonder and mysteries of creation; an extension, in parts, of Origen's thought. Light played an important role. In the context of the abyss and the darkness hanging over it, Basil reassured his listeners that darkness is not an evil power, nor is it any form of positive entity. It is 'the detestable heresy of the Manichaeans' that lays emphasis on such interpretations, and as such they should be ignored. ${ }^{16}$ The connexion between light, darkness and Manichaean dualist heresy is a theme that will appear more fully later in the hexaemeral tradition. Another theme broached by Basil but not explored in detail is the question of angels, their generation and their dwelling place. He argued that they did not exist in darkness 'but enjoyed a condition fitted for them in light and in spiritual joy'. ${ }^{17}$ Heavenly light is a reward for virtue, and there should be no surprise that it was deemed fitting for angelic powers. This heavenly light was not the created light of Gen. 1:3 but was the reason for darkness. The shadow of heaven, its light unrevealed, forms the darkness of the world.

The creation of the first light and after that the luminaries also caused difficulties for Basil. On the issue of how day and night were measured before the sun and

15 Richard William Hunt, 'The Library of Robert Grosseteste,' in Robert Grosseteste, Scholar and Bishop, ed. D.A. Callus (Oxford: Oxford University Press, 1955), 121-45, esp. 141-5. On Basil and the Hexaemeron see Andrew Louth, 'The Six Days of Creation According to the Greek Fathers,' in Reading Genesis After Darwin, ed. Stephen C. Barton and David Wilkinson (Oxford: Oxford University Press, 2009), 44-53.

16 The translation of Basil by Eustathius is followed here, taken from Eusthius, Ancienne version latine des neufs homélies sur l'Hexaéméron de Basile de Césarée, ed. Emanuel Amand de Mendieta and Stig Y. Rudberg, Texte und Untersuchungen zur Geschichte der altchristlichen Literatur, 66 (Berlin: Akademie-Verlag, 1958), as Basil-Eustathius, Hexaemeron, 2.4 (Mendieta and Rudburg, 22): 'exsecrabilis Manichaeorum secta'. For the Greek critical edition see Basile de Césareé, Homélies sur l'Hexaéméron, ed. Stanislas Giet (Paris: Cerf, 1968). A convenient English translation of the Greek is Basil the Great, The Treatise De Spiritu Sancto, the Nine Homilies of the Hexaemeron, and the Letters of Saint Basil the Great, Archbishop of Caeserea, trans. Blomfield Jackson (Edinburgh: T\&T Clark, 1895).

17 Basil-Eustathius, Hexaemeron 2.5 (Mendieta and Rudburg, 25): 'sed in luce, et laetitia decentem sibi habitum possidebat.' 
moon, he posited primitive light being dragged forward and back through God's mandate: 'following this primitive light spread abroad in the air or withdrawn in a measure determined by God, that day came and was followed by night. ${ }^{18}$ of the sun and moon's creation, Basil pointed out that they are not the origin of light, and thence come after its creation, the sun is a vehicle for that original light. A distinction is drawn between the brightness of the object and the body of light. Basil conceded this is difficult to conceive but argued that this does not prevent it from being possible for God. ${ }^{19}$ An analogy is also drawn between the light of the sun, and the true light of the world.

Basil's underlying principle and theme emerges here: the exaltation of the Creator in and through creation. Great weight is placed by Basil on the gift of light as the means through which the beauty of the universe might be perceived. Part of the beauty of light is its subtle quality, and Basil dismisses objections that so simple and homogenous an essence like light cannot be beautiful since there can be no symmetry of parts. It is a substance of beauty in its own right, and in terms of future advantage: there were no eyes around on the first day to perceive it anyway. ${ }^{20}$ The physical properties of light, Basil expounds as follows:

The air was illuminated by the light with which it was mixed, and extended, by [the extension of] its outer limits, the sharp penetration of its proper brightness in every direction. [The light] was above in the aether and close to heaven. In its breadth it reached both the northern regions and the southern, the eastern as well as the western, for indeed the nature [of aether] is lucid and transparent, so that light suffers no delay or passage of time passing through it. In the same way that air directs our sight to the objects seen without a single moment of time, so also the procession of light, swiftly and participating in every speed, floods throughout every extent of what it encompasses. In an instant it lighted up the whole extent of the world ( ... ) For the aether is such a subtle substance and so transparent that it needs not the space of a moment for light to pass through it. Just as it carries our sight instantaneously to the object of vision, so without the least interval, with a rapidity that thought cannot conceive, it receives these rays of light in its uppermost limits. ${ }^{21}$

18 Basil-Eustathius, Hexaemeron 2.8 (Mendieta and Rudburg, 28): 'sed diffusione principalis luminis, modo se subducentis, modo denuo reducentis, secundum divinam praeceptionem dies fiebat, noxque sequebatur.'

19 Basil-Eustathius, Hexaemeron 6.3 (Mendieta and Rudburg, 72-3).

20 Basil-Eustathius, Hexaemeron 2.7 (Mendieta and Rudburg, 27).

21 Basil-Eustathius, Hexaemeron 2.7 (Mendieta and Rudburg, 27): 'Aer autem inlustrabatur ex ea luce quae sibi erat admixta, acutamque penetrationem proprii fulgoris, ubique per omnes suos terminos intendebat. Sursum enim aetheri erat coeloque vicinus; latitudine autem boreales simul et australes, eoasque partes, necnon et occiduas contingebat, quippe cujus natura lucida est atque perspicua, propter quod nullas moras aut tempora lux per eum commeans sustinebat. Sicut enim obtutus nostros, sine ullo momento temporis, aer mox ad ea dirigit quae videntur; ita lucis accessum velociter, et omni celeritate perceptum, per omnes fines suae complexionis infudit.' 
The instantaneous transmission of light is worth noting, for comparison with Grosseteste, although it should be noted also that it is not light by its own agency, in Basil's opinion, that spreads so far and so fast, but through the quality of the aether.

It is in the final analysis that physical creation provides the most interest for Basil. To his audience at the beginning of the sixth homily, on the work of the fourth day, he stated:

Therefore, if at some point on a clear night you had gazed, upwards at the inexpressible beauty of the stars, I believe that you would have inquired concerning the Creator of all things, who it was that dotted the heaven with such a variety of flowers, and how it is that more usefulness than beauty can be demonstrated in the things that can be; and moreover, if at some point, reasoning with a clear mind, you had considered the daily miracles, and by reasoning concerning visible things you had found your way in thought back to him who is held to be invisible, then you would have come immediately and eagerly to hear [about him], showing yourself worthy of this noble and blessed contemplation by your alacrity. ${ }^{22}$

Basil's work remained an influence within the Greek theological tradition, in the immediate term on Gregory of Nyssa and Gregory Nazianzen, and in the longer term, well into the Middle Ages and beyond.

Basil's text became influential in the medieval west not only through the Latin translation produced by Eusthatius in around $400 \mathrm{AD}$, but also through the Hexaemeron of Ambrose. The works of Basil and Ambrose are closely related. ${ }^{23}$ The same balance of interest occurs, with heavy emphasis placed on the creation of plants, fish, birds and animals. Ambrose did get to finish his work, and the last section on the making of man includes a great deal of material derived from Galen. The same underlying insistence that creation is a work of God, and that the worker can be contemplated in his work pervades Ambrose's homilies as much as Basil's. Now common topics are discussed, for example, darkness is an accident, and the Manichees are wrong to attribute to it any form of independent power.

On the creation of light, Ambrose underscores the connection between light and beauty and the importance of its place in allowing God's creation to be perceived.

\footnotetext{
22 Basil-Eustathius, Hexaemeron 6.1 (Mendieta and Rudburg, 70): 'Itaque si quando sub serenitate nocturna, ineffabilem siderum pulchritudinem desuspexisti, credo te captum de rerum omnium conditore quaesisse, quis floribus ejusmodi coelum variaverit, et quomodo in iis quae cernuntur major delectatione probatur utilitas, itemque si interdiu, sobria mente discutiens, considerasti diurna miracula, per visibiliumque rationem, eum qui habetur invisibilis reputasti, omnino promptus ad audiendum venisti, dignum te demonstrans celebritate honesti hujus beatique spectaculi.'

23 F.E. Robbins was unfair when, following Jerome, he stated that 'as an independent work the Hexaemeron [of Ambrose] has little value' in The Hexaemeral Literature: A Study of the Greek and Latin Commentaties on Genesis (Chicago: University of Chicago Press, 1912), 58. On Ambrose see John Moorhead, Ambrose: Church and Society in the Late Roman World, The Medieval World (London: Longman, 1999), 72-3, and see also Rainer Henke, Basilius und Ambrosius über das Sechstagewerk: Eine vergleichende Studie (Basel: Schwabe, 2000).
} 
There are however some differences of emphasis in what follows. Ambrose speaks of the immediate effulgence of light in this way:

Suddenly, then, the air became bright and darkness shrank in terror from the brilliance of the novel brightness. The brilliance of the light which suddenly permeated the whole universe overwhelmed the darkness and, as it were, plunged it into the abyss. ${ }^{24}$

There is less here about the agency of aether, and a more straightforward statement of the instantaneous spread of light. Light is assessed with more specific attention by Ambrose, although he does pursue the line adopted by Basil, that light is valued, not only on account of its splendour but also as a result of its usefulness.

\section{Grosseteste: Hexaemeron}

Both Ambrose and Basil base their interpretations of light on the material world, and it is the world of creation that acts as the prism for their theological observations. In this they are followed by Grosseteste, who treats Basil, especially, in a respectful but critical manner, using the older thinker's ideas to stimulate fresh interpretation. In the course of remarks on the first day of creation and the earth as void and empty, with darkness upon the face of the deep, Grosseteste puzzles through a variety of positions. The face of the deep is the diaphaneity, transparency, and natural potency that allows it to receive illumination, but 'there was still darkness over this face, since there was no light yet which could be poured out and illuminate the deep'. ${ }^{25}$ Or, as Basil says, the light of the first heaven existed but was projected outwards. In tropological and allegorical senses the interpretation offered is one of purification through rational process, the completion of which takes away the darkness. Grosseteste then introduces notions that are more original. The deep, he notes,

24 Ambrose, Exameron 1.9, in Sancti Ambrosii Mediolanensis Opera IV, ed. C. Schenkl, Corpus Scriptorum Ecclesiasticorum Latinorum 32/1 (Leipzig: Verlag der Österreichischen Akademie der Wissenschaften, 1897), 33: 'Resplenduit igitur subito aer, et expaverunt tenebrae novi luminis claritate. Repressit eas, et quasi in abyssos demersit repente per universa mundi fulgor lucis infusus.' English translation from Saint Ambrose, Hexameron, Paradise and Cain and Abel, trans. John J. Savage, The Fathers of the Church, 42 (New York: Fathers of the Church, 1961), 39.

25 Grosseteste, Hexaemeron 1.18.1 (Dales and Gieben, 77): 'Super hanc faciem adhuc errant tenbre, quia nondum erat lux que superfusa abyssum illuminaret.' English translation from Robert Grosseteste, On the Six Days of Creation, trans. C.F.J. Martin, Auctores Britannici Medii Aevi, 6(2) (Oxford: Oxford University Press, 1996), 76. 
is said to be dark ( ... ) because of the privation of forms, which is light, which it has not yet received from the higher thing that forms it. For every form is some kind of light, since every form shows itself forth. ${ }^{26}$

An intimate connexion exists between light and creation; light lies at the basis of each form, it is the essence of creation. This is extended by Grosseteste in his remarks that the earth was invisible not because there were no human beings to see it, but because there was no light. Without light there are no forms, and formless things are invisible to the understanding, just as dark cannot be seen by the physical eye.

Part 2 of Grosseteste's Hexaemeron deals most closely with the subject of light, the verse for comment, 'God said be light made'. Grosseteste points out first that this was said 'in the Word that was co-eternal with him'. In other words, there is no other agency than God from whom light and creation springs, nor any other creature. Moreover, the association with the Word of God reveals, according to Grosseteste that creation is also a trinitarian action; the Holy Spirit has already moved over the waters, and now the Word, 'co-eternal with the Father, since he is the shining of the light' is included. These aspects established, Grosseteste then moves to consider the implications of the physical light created, light and beauty, and the spiritual senses of light especially in terms of knowledge.

In terms of the literal interpretation, Grosseteste covers the issue of the chronology of the creation of light: God orders light to be on the first day, but the sun and moon make no appearance until the third. Bede and Jerome are cited as proponents of the view that there were days and nights, days indicated by the presence of light, and night by its shadow. Nevertheless, in those three days the light of day was not as bright as now and had no power to warm or heat. By contrast Basil states that there were no days and nights during the first three days and posits, rather, that the original light poured out and was then pulled back, creating a form of day and night. Here Grosseteste is openly critical of his sources: seeing no reason why light should creep around the world following Bede and Jerome and no reason at all for Basil's suggestion. ${ }^{27}$ Furthermore, Grosseteste is led from these conflicts within the sources to the observation that there was an instantaneous creation, including light, and that the measure of days as recorded in the Genesis narrative is not literal, all things were co-created. When he comes to deal with the creation of lights in the firmament, he once again refuses to offer hard and fast opinions on the matter, stating simply that, 'those shining bodies, then, whether they shine in virtue of the first light, or

26 Grosseteste, Hexaemeron 1.18.2 (Martin, 77; Dales and Gieben, 78): 'Tenebrosa vero dicta est abissus ( ... ) propter privacionem forme que lux est, quam nondum suscepit a superiore formante. Omnis enim forma aliquod genus lucis est, quia omnis forma manifestativa est.'

27 Grosseteste, Hexaemeron 2.4-5 (Dales and Gieben, 88-92). 
in virtue of a light co-created with them on the fourth day, as our authorities hold, were made to divide day and night. ${ }^{28}$

Co-creation and the importance of instantaneous creation lie close to the heart of Grosseteste's thought on physical light, at the point in the Hexaemeron where he uses and adapts material from his scientific opuscula, in this case the De luce. A comparison of both works reveals how the adaptation is made, what is borrowed and in what context, and what is left out. Grosseteste introduces the topic by justifying why the physical properties of light are relevant, namely, that if these are understood, then the mystical signification of light will be better understood. The literal sense guides mystical understanding, the sensible leading to that which lies beyond sensation, science at the service of wisdom: scientia at the service of sapientia. Grosseteste goes on to describe the physical qualities of light in the following way:

\begin{abstract}
The nature of light is such that it multiplies itself in all directions. It has what I might call a selfgenerativity of its own substance. For of its nature light multiplies itself in all directions by generating itself, and it generates all the time that it exists. For this reason it fills the place around it all at once: the light which is by nature first generates the light that follows it, and the light that is generated at the same time comes to be, and exists, and generates the light that next follows it, and the following light does the same for the light that follows it: and so on. That is why in one instant one point of light can fill a whole sphere. If light moved by local motion, as some have imagined, the lighting up of a dark place would have to be successive, not all at once. And perhaps it is because light is self-generative by its nature, that it is also self-manifesting. Perhaps its self-generativity is its manifestability. ${ }^{29}$
\end{abstract}

This passage draws its inspiration from the De luce, but in a controlled and circumscribed manner. In the De luce light is given a clearer causative role in the material world, and the treatise describes in detail the implications of the self-replicating quality of light as the first form of the material universe. This position is summarised by Grosseteste:

So light, which is the first form in created first matter, by its nature infinitely multiplying itself everywhere and stretching uniformly in every direction, at the beginning of time, extended mat-

28 Grosseteste, Hexaemeron 5.6.1 (Martin, 163; Dales and Gieben, 161): 'Ipsa autem corpora lucentia, sive luceant ex illa luce primaria, sive ex luce in illis quarto die concreata, sicut nostri auctores, facta sun tut dividant diem et noctem.'

29 Grosseteste, Hexaemeron 2.10.1 (Martin, 97-8; Dales and Gieben, 97-8): 'Est itaque lux sui ipsius naturaliter undique multiplictiva, et, ut ita dicam, generativitas quedam sui ipsius quodammodo de sui substancia. Naturaliter enim lux undique se multiplicat gignendo, et simul cum est generat. Quapropter replet cicumstantem locum subito; lux enim prior secundum locum gignit lucem sequentem; et lux genita simul gignitur et est et gignit lucem sibi proximo succedentem; et illa succedens adhuc succedentem ulterius; et ita consequenter. Unde in instanti uno lucis punctus replere potest orbem lumine. Si autem lux esset lata locali motu, sicut ymaginantur quidam, necesse esset obscurorum locorum illuminacionem fieri non subito, sed successive. Et forte inde quod lux est naturaliter sui generativa, est eciam sui manifestativa, quia forte sui generativitas ipsa manifestabilitas est.' 
ter (which it could not leave), drawing it out along with itself in a mass the size of the world machine. ${ }^{30}$

Where the rest of the De luce explores the formation of the physical universe, the Hexaemeron does not. In a manner similar to Grosseteste's epistolary response to his pupil Adam of Exeter on the question as to whether God is first form, Grosseteste in the Hexaemeron deals with a theological question, using science as an analogy within an exegetical exercise. ${ }^{31}$

Having established the properties of light, Grosseteste proceeds to give a workedup example of why this is useful, again drawing from the scientific opuscula, this time the De colore, with a similar process of extraction from and adaption of his source. Light, Grosseteste states, has two senses, the first is a bodily substance, but very subtle and close to non-corporeity, a substance that is self-generative; the second is an accidental quality that proceeds from the natural generative action of the substance of light. Light in this way is, as Augustine's Confessions records, the queen of colours, since, according to Grosseteste, it brings them into existence by being embodied and moving them by being shone on to them. ${ }^{32}$ This is summarised as follows:

For colour is light embodied in a transparent thing with the quality of humidity [containing the element of water]. This colour cannot generate its likeness in the air because it is slowed down by its embodiment, but when light is shone on to it, it moves to the act of generating its likeness in the air. ${ }^{33}$

This is in fact an additive understanding of colour to the scientific treatise composed, probably, in the 1220s. There is nothing in that treatise about additional light being required to super-charge the embodied light, that is colour, which begins with the

30 Robert Grosseteste, De luce, edited by Cecilia Panti, 'Grosseteste’s De luce: A Critical Edition,' in Robert Grosseteste and His Intellectual Milieu: New Editions and Studies, ed. John Flood, James R. Ginther, and Joseph W. Goering, Papers in Medieval Studies, 24 (Toronto: Pontifical Institute of Mediaeval Studies, 2013), 227: 'Lux itaque, que est forma prima in materia prima creata, seipsam per seipsam infinities undique multiplicans et in omnem partem equaliter porrigens, materiam quam relinquere non potuit, secum distrahens in tantam molem quanta est mundi machina, in principio temporis extendebat.' English translation by Neli Lewis, 'Robert Grosseteste’s On Light: An English Translation,' in Robert Grosseteste and His Intellectual Milieu, 240.

31 Grosseteste, Epistolae 1 (Luard, 1-197; Mantello and Goering, 35-49).

32 Augustine, Confessionum libri XIII, 1. 10, c. 34, ed. Martin Skutella and Luc Verheijen, Corpus Christianorum Series Latina, 27 (Turnhout: Brepols, 1981), 182-4.

33 Grosseteste, Hexaemeron 2.10.2 (Martin, 99; Dales and Gieben, 99): 'Lux namque incorporata in perspicuo humido color est; qui color sui speciem in aere propter incorporacionis sue retardacionem per se generare non potest; sed lux colori superfusa movet eum in generacionis sue speciei actum.' 
simple statement that 'Colour is light in a transparent medium'. ${ }^{34}$ Grosseteste in the Hexaemeron offers an account of the generation of colour that moves beyond the previous work. He concludes that without light all bodies are hidden and unknown, supporting the exegetical point that light reveals creation, manifests its beauty and allows order to be perceptible.

Light in its physical qualities is then an agent, or perhaps the agent, of order. The nature of light as Grosseteste sees it is also an explanation for his comments on the interpretations of Jerome, Basil, and Bede. A connection between order, knowledge and light is brought out fully in the Hexaemeron. Grosseteste emphasises the position of light within the beauty and order of the universe. Basil is cited with reference to this line of thought, 'The first utterance of the Lord made the nature of light and scattered the darkness, rid us of sadness, and at once brought forth every pleasant and happy appearance. ${ }^{35}$ By corollary the absence of light shows the lack of order and happiness. In this way 'darkness means the vicious lack of ordering of love', according to our author. Grosseteste emphasises the ordering of light which made light knowable, bringing form to formless matter with Eph. 5.13 to the fore: 'All that is manifest is light.' For Grosseteste, light is also made in the church and in any holy soul when rational knowledge engages in contemplation of what it should, namely the divine, and specifically the Trinity. Reason and rationality then are parts of created light: the vision of the truth through contemplation. If light is made in the church, as the vehicle for speculation on matters rational and spiritual, Grosseteste relates its propagation to another of his theological concerns, namely pastoral care. As he states,

in the allegorical sense the light is the wise and spiritual prelates of the church, who strive with the knowledge of truth, with love and with outward shining of good works. The darkness is their subjects who are wrapped in the darkness of ignorance, and are animal and carnal. ${ }^{36}$

34 Robert Grosseteste, De colore, edited in The Dimensions of Colour, Robert Grosseteste's De colore, ed. and trans. Greti Dinkova-Bruun et al. (Toronto: Pontifical Institute of Mediaeval Studies, 2013), $16-7$.

35 Grosseteste, Hexaemeron 2.10.3 (Martin, 99; Dales and Gieben, 99): 'prima vox Domini naturam luminis fabricavit ac tenebras dispulit, meroremque dissolvit et omnem speciem letam iocundamque subito produxit.'

36 Grosseteste, Hexaemeron 2.9.2 (Martin, 96-7; Dales and Gieben, 96-7): 'Item allegorice lux ecclesie sunt prelate, sapientes et spiritales, qui lucent veritatis cognicione et amore bonorum operum exterior spendore. Tenebre vero sunt subditi tenebris ignorancie involuti et animales et carnales.' 


\section{Grosseteste: Le Château d'Amour and De cessatione legalium}

Provision for pastoral care probably lies behind the composition of Grosseteste's Chateau d'Amour. A long and involved piece, the poem announces itself as written in romanz for those who have little learning and no knowledge of Latin. Given that the earliest manuscripts attribute the poem to Grosseteste as Master, a date before 1235 is likely; given the pastoral focus, composition for use by the Oxford Franciscans is possible. ${ }^{37}$ As Evelyn Mackie points out, the poem is 'essentially biblical translation with commentary', rather than courtly literature. ${ }^{38}$ The poem is structured around the creation story, the fall of humanity, and, following Anselm of Canterbury, the necessity of the God's incarnation as Jesus Christ.

I will tell of the world, why it was made, and then how it was given to Adam our first father. I will tell how paradise was also given, with so much joy and honour, and finally heaven too, then how it was lost, restored and given back again. ${ }^{39}$

Grosseteste states that he will not dwell on the six days of creation since that is a familiar story, but chooses to emphasise the brightness of the luminaries as part of a longer argument that all creation had greater virtue before Adam and Eve's sin.

In the beginning when God, who knows and sees all things, had created heaven and earth with all their splendour; the sun was seven times brighter than it is at present, and the moon, illuminating the night, was as bright as the sun shines now. Do not think that this is foolish, for this is what Isaiah says. ${ }^{40}$

Light, though not absent from the poem, is not its dominant theme. Creation, redemption and unity provide the main focus.

37 Eveyln A. Mackie, 'Robert Grosseteste's Anglo-Norman Treatise On the Loss and Restoration of Creation, Commonly Known as Le Château d'Amour: An English Prose Translation,' in Robert Grosseteste and the Beginnings of a British Theological Tradition, ed. Maura O'Carroll (Rome: Istituto Storico dei Cappuccini, 2003), 150 - 6; see also Andrew Reeve, Religious Education in Thirteenth Century in Thirteenth-Century England: The Creed and Articles of Faith (Brill: Leiden, 2015), 143.

38 Mackie, 'Le Château d'Amour,' 151.

39 Robert Grosseteste, Le Château d’Amour, 11. 29-36, ed. J. Murray (Paris: Librairie Champion, 1918), 90: 'Del mund dirai pur quci fu fet, / E pus cornent donez est / A Adam nostre premer peere, / E paraïs en teu manere, / Od tant de joie od tant d'onur, / E puis li ciel a chief de tur, / E cornent fu pus perduz/ Pus resterez e pus renduz.' English translation from Mackie, 'Le Château d'Amour,' 160. 40 Grosseteste, Le Château d'Amour, 11. 44-54 (Murray, 90): 'Kant Deus a le comencement, / Ki tut bien set e tut bien veit. / Ciel e terre fet aveit / Od tuz lur aturnemens, / Li soleil fu a iceu tens / Set fez plus cler ke ne est ores, / E la lune si cler lores / Cume li soleil ore luit / Luseit adonke de nuit. / Ne le tenez pas a folie / Kar ce est le dit Ysaïe.' English translation from Mackie, 'Le Château d'Amour,' $160-1$. 
The biblical story of the genesis of original sin is punctuated by a parable of a king and his four daughters, Truth, Justice, Mercy and Peace, which underlines the theme of unity that runs through the whole: the daughters united bring peace to the kingdom. Further discussion of the incarnation follows closely Anselm of Canterbury's reasoning on the necessity that God became human:

No angel could redeem or raise man from the dead. In every way it was necessary that God become man-man to suffer death, and God to rise again, else whatever was in the world would have perished. Hear now of such great love, such great mercy, such great gentleness, that God came down from heaven for the sake of his sheep which was lost. ${ }^{41}$

The well-known allegorising of Mary as a castle in which Christ was secure, a place of goodness and light suitable for God to shelter within, provides the stage for the dynamics of the incarnation. The centre of the castle includes a throne of ivory 'shining more brightly than daylight in midsummer' and cast about with a rainbow. The remainder of the poem gives an extended explanation of the names of Christ given in Isaiah, and a description of the atoning work of Christ. In this last work the Devil is given a full role to play, with rights that require to be overthrown, which runs counter to Anselm's arguments negating the rights of the Devil. For Grosseteste:

When the world was created and Adam had first sinned, then the evil one had so much power that he caused the world to do his will, for the one for whom the world was made had been snared into his power. ${ }^{42}$

A set-piece debate between the Devil and Jesus plays out; the former fooled that the latter is human, asserts jurisdiction over sin and death. Christ, being divine and human, is able to pay the ransom owed, and wins humanity back. This is described by Grosseteste in terms reminiscent of Rufinus of Aquileia's Expositio Symboli, from a line of thought originating in Gregory of Nyssa. The purpose of Grosseteste's poem was similar to that of the Expositio in seeking a straightforward account of one of the principal articles of faith:

41 Grosseteste, Le Château d'Amour, ll. 475-86 (Murray, 102): 'Ne angle ne pot rechater. / Ne home de mort relever. / En tute fin donc covenist, / Ke Deus home devenist, / Home pur la mort suffrir, / E Deus pur de mort revenir; / Kar autrement peeri eüst / Tut kant ke en le siècle fust. / Oreoiez de si grant duçur. / Si grant pité, si grant amur, / Ke Deus de le ciel descendi / Pur sa owaille k'il perdi.' English translation from Mackie, 'Le Château d'Amour'' 165. See Anselm, Cur Deus homo, 1. 2, c. 6 which summarises the argument for necessity and the God-man in S. Anselmi Cantuariensis archiepiscopi opera omnia, 6 vols, ed. Franciscus Selesius Schmitt (Edinburgh: Nelson, 1946-61), 2:101. The edition was reprinted with new editorial material as S. Anselmi Cantuariensis archiepiscopi opera omnia, 2 vols, ed. Franciscus Salesius Schmitt (Stuttgart-Bad Cannstatt: Frommann, 1968-84).

42 Grosseteste, Le Château d'Amour, ll. 1295-1300 (Murray, 125): 'Kant le munde fu crié, / E Adam out primes pechié, / Donc out le Malfé tant poër / Ke de le mund fist sun voler, / Kar lui pur ki le mund fut fet / En sun poër out attret.' English translation from Mackie, 'Le Château d'Amour,' 174. 
And so the adversary expected to gain everything by his death, but he was caught, the glutton, like a fish on a lure which swallows the worm and become impaled on the hook. ${ }^{43}$

The end of the poem emphasises the unity of God in Christ, in the creative act and in the redemptive act. The use of Anselmian ideas by Grosseteste is curious; elements are taken on wholesale, such as the necessity of incarnation, where others, for example, the rejection of the rights of the devil, are not adopted.

A similar emphasis on unity, and a transformation of an Anselmian argument is to be found in On the Cessation of the Laws written probably in the early 1230s, drawing on older lectures in a similar fashion to the Hexaemeron. A four-part work with a complex structure, the treatise deals with an interpretation of the economy of salvation that moves through the relation of the Old and New Testaments and the person and role of Jesus. The theme of unity in creation and between Creator and creation emerges powerfully in Part 3, where Grosseteste moves beyond the arguments for the necessity of the incarnation proposed by Augustine and Anselm.

Instead, Grosseteste presses for the notion that the incarnation would have happened even without man's fall, to fulfil and unite creation. Human nature is both corporeal and rational. Grosseteste concludes with the chorus that:

If, then, God should assume man in a personal unity, all creation has been led back to the fullness of unity; but if he should not assume man, all creation has not been drawn to the fullness of unity possible for it. If, therefore, we leave aside the fall of man it is nonetheless fitting that God assume man into a personal unity, because he could do it and it would not be inappropriate for him to do it; but even more, it would be appropriate, because without this the created universe would lack unity. But if this were done all creation would have the fullest and the most fitting unity, and through this all natures would be led back into a circular fulfilment; because without God assuming man into a personal unity, one finds in the above-mentioned way a certain joining of angels and men. ${ }^{44}$

43 Grosseteste, Le Château d'Amour, 1l. 1103-8 (Murray, 119): 'Adonk qui de li Adversier / Par sa mort trestut gaaignier. / Mes il fu pris li gluton / Cum est a le heim li peisson.' English translation from Mackie, 'Le Château d'Amour,' 172. Compare with Rufinus, Expositio Symboli, in Tyrannius Rufinus, Opera, ed. M. Simonetti, Corpus Christianorum Series Latina, 20 (Turnhout: Brepols, 1961), 16: 'Ut divina Filii Dei virtus velut hamus quidam, habitu humanae carnis obtectus (...) principem mundi invitare possit ad agonem: cui ipse carnem suam velut escam tradens, hamo eum divinitas intrinsecus teneret insertum' [So that the divine virtue of the Son of God, like a kind of hook hidden in the form of human flesh ( ... ) could lure the prince of the world to a contest; that the Son of God might offer him his human flesh as bait, and that the hidden divinity might hold him fast with its hook].

44 Robert Grosseteste, De cessatione legalium 3.1.28, ed. Richard C. Dales and Edward B. King, Auctores Britannici Medii Aevi, 7 (London: Oxford University Press, 1986), 131: ‘Si igitur assumat Deus hominem in unitatem persone, reducta est universitas ad unitatis complementum. Si vero non assumat, nec universitas ad unitatis complementum sibi possibile deducta est. Circumscripto igitur hominis lapsu, nichilominus convenit Deu assumere hominem in unitate persone, cum et hoc possit facere nec dedeceat ispum hoc facere; sed multo magis deceat, cum sine hoc careat universitas unitate. Hoc vero facto, habeat universitas plenissimam et decentissimam unitatem, redacteque sint per hoc 
The third book goes on to offer a vision of the universe in which Christ would have become incarnate even had Adam and Eve not sinned. The whole Christ, Christus integer stands then to unite creation and creator, a cosmic re-evaluation of the humancentred doctrines of incarnation developed in the $12^{\text {th }}$ century by Anselm, Abelard and Hugh of St Victor. It is the figure of the Christus integer, it should be noted who stands at the head of the Hexaemeron as well, as the object of Christian thought, of theology, which is properly a wisdom rather than a science.

\section{Summa Halensis}

As Ginther has observed, the intensity with which Grosseteste approached the question of the incarnation without original sin inspired later-13 ${ }^{\text {th }}$-century thinkers to their own views on the subject, amongst them Alexander of Hales, Albert the Great, Aquinas, and Bonaventure. ${ }^{45}$ The issue emerges also in the Summa Halensis. ${ }^{46}$ The position adopted here is similar to Grosseteste in its conclusions, that it is to be conceded without prejudice that, even if human nature had not fallen, even so there would have been a fittingness for incarnation, although the argumentative means are different. The notion that even had human nature not fallen, there would have been a fittingness for the incarnation, is argued on the basis of the blessedness in God and within humans. Human beings ought to be wholly made blessed in God, God ought to be corporeal and perceptible to the senses; but it is not fitting that God should assume any corporeal nature whatever, but only human nature.

It is fitting, therefore, that there should be a union of divine nature with human [nature] in a union of personhood, in order that there should be completeness in the entirety of things, that is, so that, as there are three persons in one nature and three persons in three natures, so should there also be three natures in one person, that is, divinity, body, and soul. ${ }^{47}$

To the counter-position that the incarnation without redemption is pointless, the Summa Halensis moves to Bernard and the role of the devil, in particular his envy

omnes nature in complementum circulare; quia sine eo quod Deus assumat hominem in unitatem persone, est reperire modo supradicto concatenacionem quandam ab angelo usque ad hominem.' English translation from Robert Grossesteste, On the Cessation of the Laws, trans. Stephen M. Hildebrand, The Fathers of the Church: Medieval Continuation, 13 (Washington, DC: The Catholic University of America Press, 2012), 167.

45 Ginther, Master of the Sacred Page, 128.

46 Alexander of Hales, Doctoris irrefragabilis Alexandri de Hales Ordinis minorum Summa theologica (SH), 4 vols (Quaracchi: Collegium S. Bonaventurae, 1924-48), SH VI, In1, Tr1, Q2, Ti2 (n. 23), pp. 41-2.

47 SH VI, In1, Tr1, Q2, Ti2 (n. 23), p. 41: 'Convenit ergo quod sit unio divinae naturae ad humanam in unitate personae ut sit in rerum universitate perfectio, ut sicut tres personae in una natura et tres personae in tribus naturis, ita tres naturae in una persona, scilicet divinitas, corpus et anima.' 
for the blessed state of humanity. By tempting humans to sin, the devil would make them forfeit their unifiability to God. In so doing the devil revealed that he understood the union of human nature to God to be associated with a pre-lapsarian state. The fall in this way was an impediment to unity and the opening for the devil's temptations to be effective. The fall then, as impediment, does nothing to diminish the fittingness of the incarnation in a pre-sinful state.

Other ideas developed by Grosseteste over the course of his various treatments of the concept of creation, for example, on light find a similar, slightly dissonant resonance in the Summa Halensis. For instance, the Summa Halensis uses light as a sensible reality by which the mystical realities beyond sensation can be understood, in the same way as Grosseteste. Divine grace, a wholly mysterious agent far surpassing human perception, can be understood as resembling light, the Summa states, but only in a clearly defined sense. ${ }^{48}$ Some understood light in the air to be a body, or in other words a substance; but in this sense the comparison breaks down, since grace, whatever it is, is not a substance. ${ }^{49}$ On a different understanding, light was seen as a form bringing out the goodness and perfection of air; this perfection is to be transparent: ${ }^{50}$

It should therefore be said that the comparison of light to created grace holds good in as much as light is said to be a form and following from the fact that grace is accidental to the soul itself and depends on it as the subject in which it exists, while depending on uncreated grace as that from which it is. ${ }^{51}$

The Summa subsequently goes on to discuss various ways in which an accident could depend on a substance, further specifying the ways in which this analogy can be helpful for the human understanding of grace. The salient point at present is that the idea of light as form is invoked to explain mystical realities, in a way that Grosseteste had pioneered in the Latin West.

This is not an isolated example in the Summa Halensis. A similar argument is also invoked in Book 2, concerning the question of what sort of perfection or completion is alluded to in the part of Genesis that speaks of the creation of the heavens and the earth:

48 SH I, P1, In1, Tr3, Q1, M1, C2 (n. 73), p. 114.

49 SH IV, P3, In1, Tr1, Q2, C1, Ar3 (n. 610), Ad obiecta 1, p. 962: 'Una est quod lux in aëre sit corpus, et hoc modo est substantia; sed secundum hoc non tenet illa comparatio, quia gratia non est substantia, sicut visum est.'

50 SH IV, P3, In1, Tr1, Q2, C1, Ar3 (n. 610), Ad obiecta 1, p. 962: 'Alia opinio est quod lux est forma perficiens aërem quantum ad bene esse, quod est esse perspicuitatis.'

51 SH IV, P3, In1, Tr1, Q2, C1, Ar3 (n. 610), Ad obiecta 1, p. 962: 'Dicendum ergo quod comparatio lucis ad gratiam creatam tenet in quantum lux dicitur forma et secundum quod gratia accidit ipsi animae et dependet $\mathrm{ab}$ ea sicut a subiecto in quo est, a gratia autem increata sicut ab illo a quo est.' 
'Perfection' refers to the creation of these [that is, the heavens and the earth] both as to matter and as to form. As to matter, when it is said: 'In the beginning, God created' etc.; as to form when it is said: 'Let there be light' etc. ${ }^{52}$

This passage comes in the wider context of discussion on the six days of creation, inserted in a manner similar to that of Peter Lombard in the Sentences. A useful comparison may be made between Grosseteste and the Summa Halensis taking a particular example of the question whether the primordial light ceased to exist once the sun was made. In this connection Grosseteste notes varying opinions amongst the Fathers: whether the luminaries shine by virtue of the first light (Greeks) or as a result of light co-created with them on the fourth day (Latins). ${ }^{53} \mathrm{He}$ also goes on to explore the relation between sunlight and moonlight, and the dependence of the latter on the former. The moon receives its light from the sun and is diminished accordingly, though its power over the earth is still considerable. ${ }^{54}$

The question posed by the Summa Halensis takes a different approach, again to a similar end-the conclusion of the discussion is that all luminous bodies were made from the division of the first light. The perfection and nobility of the first day also indicate that the light made then was perfect, not diminished, and fitted for the purpose for which it was made. In the course of coming to this conclusion, the Summa opens and addresses seven points, an argument of congruence-for God to have made something that ceased to exist so quickly would not be congruent with his wisdom; an argument of hierarchy-what is more complete does not give way to the less complete, and, with John of Damascus cited in support, the works of the first and seventh days were more noble than all others; similarly the 'day' of the fourth day must therefore have been less noble than the first day, so first light was more noble than sunlight; God as the most sufficient of craftsmen would produce from the start a perfected work rather than imperfect; whether if first light remained with the light of the luminaries would it change-answered by the notion that this light was divided for the sun, moon and stars; where the first light was in relation to the sun and stars; and, finally, why if light was divided to form the perfection of stars and sun Saturn moves more slowly than the other planets, when, as lighter, it would seem more logical for it to move faster.

Here then, albeit it in a different way to Grosseteste, a blend of scientific knowledge from questions posed in a theological frame. The more detailed response in the Summa Halensis extends the points made above and in the same vein. On Saturn's movement, the discussion concludes that the planet should not be thought to move slowly as a result of its greater density, but rather on account of the fact

52 SH II, In3, Tr2, Q3, Ti3, M2, C6, Ar3 (n. 305), Respondeo, p. 366: 'Perfectio designat conditionem horum et quantum ad materiam et quantum ad formam. Quantum ad materiam, cum dictum est: "In principio creavit" etc.; quantum ad formam, cum dictum est: "Fiat lux" etc.'

53 Grosseteste, Hexaemeron 5.5-6 (Dales and Gieben, 160-3).

54 Grosseteste, Hexaemeron 5.22 (Dales and Gieben, 181-3). 
that it has the furthest of all of the planets to move. When it comes to the nature of light, the comparison to Grosseteste is more intriguing. The Summa Halensis states, as noted above, that all of the luminaries were made from the division of the first light, but goes on to the position that:

Yet one should not posit in it the nature of lightness and heaviness, because light of its nature extends and diffuses itself; therefore, it would diffuse itself in all directions unless it has an obstacle, in a straight line [that is, up and down] and in breadth and in a circle, as is evident from the light of a candle in a house..$^{55}$

The statement that light diffuses in all directions echoes Grosseteste's De luce and the adapted version that formed part of the Hexaemeron. Straight, rectilinear, and circular motion are features too of Grosseteste's scientific opuscula from the description of vowel formation in De generatione sonorum, to the treatises De motu corporali et luce and De lineis, the latter two treatises dating from the mid to late 1220 s. $^{56}$ The extent to which the Summa Halensis develops ideas from Grosseteste in this discussion, alongside others, is intriguing, speaking to the variety of sources that make an appearance in the compilation, and, perhaps, to the more direct influence of particular texts.

As seen earlier, Grosseteste certainly knew of Alexander of Hales, John of La Rochelle and the Franciscan school at Paris. His role as lector to the Oxford community from 1229 to 1230, and the continuing relationship with Adam Marsh from his conversion to the order, as well as a possible period in Paris in the mid 1220s, create the circumstances for exchange of ideas on the subjects of mutual theological interest. The lines of transmission on this score remain multiple, metaphorical as well as enacted in the world. In his letter collection Grosseteste frequently reserves lucent vocabulary for Franciscan brothers, emphasising in their radiation the essentially pastoral grounds for his theological vision. Interest in creation was a marker for early Franciscan thought too, established in the attitudes towards nature by Francis himself. From the Canticle of the Sun, with its basic cosmology and elemental exposition alongside the cycle of life and death, to the larks that sang above the hut where he lay dying, creation plays a vital and dynamic role in the presentation of Francis and his communities. ${ }^{57}$ That the more worked out vision of creative theology

55 SH II, In3, Tr2, Q1, C5, Ar3-4 (n. 263), Solutio, p. 324: 'Non tamen oportet ponere in ea naturam gravis et levis, quia lux de natura sua est diffusive sui: unde diffundit se undique, nisi habeat obstaculum, secundum rectum et secundum latus et circulariter, sicut patet in lumine candelae in domo.' 56 For the De generatione sonorum see The Scientific Works of Robert Grosseteste, vol. 1, Knowing and Speaking: Robert Grosseteste's De artibus liberalibus 'On the Liberal Arts' and De generatione sonorum 'On the Generation of Sounds,' ed. Giles E. M. Gasper et al. (Oxford: Oxford University Press, 2019); for the De motu corporali et luce and De lineus see the edition, Die Philosophischen Werke des Robert Grosseteste, Bischofs von Lincoln, ed. Ludwig Baur (Münster: Aschendorff, 1912).

57 On the Canticle of the Sun see Brian Moloney, Francis of Assisi and His "Canticle of Brother Sun" Reassessed (Basingstoke: Palgrave Macmillan, 2013), XXI-XXVI. This prints the standard critical edi- 
in the Summa Halensis can also be compared to Grosseteste, especially on the interlocking issues of creation and redemption, reveals both as part of the same inquiry into divine love, the consequences of sin, creation ex nihilo, and the unity of Creator with creation.

tion by Carolus Paolozzi (2009) and two English translations. For the Vita Prima by Thomas of Celano see S. Francisci Assisiensis: et eiusdem Legenda ad usum chori, Analecta Franciscana, 10/1 (Quaracchi: Collegium S. Bonaventurae, 1926). English translation from Thomas of Celano, 'The Life of Saint Francis,' in Francis of Assisi: Early Documents, vol. 1, The Saint, ed. Regis J. Armstrong, J.A. Wayne Hellmann, and William J. Short (New York: New City Press, 2011), 169-308. 